DIAKRONIKA

Vol. 18 No. 2 Th. 2018 p: 124-137

ISSN: 1411-1764 (Print) | 2620-9446 (Online)

http://diakronika.ppj.unp.ac.id

\title{
Eksistensi Kesenian Tradisional Joget Dangkong Di Pulau Panjang Kota Batam
}

\author{
Desma Yulia, Fitri Yanti \\ Desmayulia48@gmail.com \\ Universitas Riau Kepulauan
}

\begin{abstract}
The purposes of this research are to explain the existence of Dangkong dance as the Malay traditional art, namely; to know the socio-cultural functions of Dangkong dance in Malay society, to know the socio-cultural functions of Dangkong Dance at Panjang Island society, to explain the facts of what caused the change occurrence of the Dangkong Dance roles at Panjang island society. To achieve these purposes, the research activities will be divided into two stages, namely the library research and the field research. The library research focused on searching some books that are relevant to the research, while the field research conducted in the form of surveying the sampling of the location, observation and in-depth interview. Furthermore, the methods used in this research namely Clifford Geertz's ethnographic analysis. The results show that Dangkong Dance as Malay traditional art consists of several elements: (1) musical accompaniment; (2) song accompaniment; (3) ornament. Dangkong Dance performance occupies the function as the entertainment art. Dangkong Dance performance also is regarded as the complementary of the core entertainment or as a cover in the entertainment. The changes of the traditional art relate with the decreasing of public interest to Dangkong Dance and rarely the Dangkong Dance performance. Factors which led to low public interest to Dangkong Dance, namely: (1) the appearance of some new entertainment facilities; (2) the emergence of the dance art appearance that appropriates with the development of modernization in Panjang Island Batam city.
\end{abstract}

Keywords : traditional art existency, Dangkong Dance, Panjang Island

\section{Abstrak}

Tujuan penelitian ini antara lain; menjelaskan keberadaan Joget Dangkong dalam kesenian tradisional Melayu; mengetahui fungsi sosial budaya Joget Dangkong dalam masyarakat Melayu; mengetahui fungsi sosial budaya Joged Dangkong pada masyarakat Pulau Panjang; serta menjelaskan fakta apa saja yang menyebabkan terjadinya perubahan peran Joget Dangkong pada masyarakat Pulau Panjang. Kegiatan penelitian dibagi dalam dua tahap, yaitu studi kepustakaan dan riset lapangan. Studi kepustakaan dilakukan dengan mencari buku-buku yang relevan dengan topik penelitian.Kemudian riset lapangan dilakukan melalui survei di lokasi penelitian, observasi serta wawancara mendalam. Analisis data menggunakan analisis etnografi dari Clifford Geertz. Hasil penelitian menunjukkan bahwa Joged Dangkong sebagai kesenian tradisional Melayu terdiri dari beberapa unsur (1) musik pengiring; 
(2) lagu pengiring; (3) ornamen. Pementasan Joged Dangkong memiliki fungsi sebagai seni hiburan. Pementasannya merupakan pelengkap dari inti hiburan maupun hiburan penutup.Perubahan kesenian tradisonal terkait dengan menurunnya minat masyarakat pada Joged Dangkong dan rendahnya pementasan Joged Dangkong. Faktor penyebab rendahnya minat masyarakat pada Joged Dangkong, diantaranya (1) munculnya berbagai sarana hiburan baru; (2) kemunculan kesenian joged yang disukai dan sesuai dengan perkembangan modernisasi di Pulau panjang Kota Batam.

Kata kunci : eksistensi kesenian tradisional, Joged Dangkong, Pulau Panjang

This work is licensed under the Creative Commons Attribution-Share Alike4.0 International License.

\section{Pendahuluan}

Kesenian tradisional Melayu merupakan unsur mutlak dalam kebudayaan di mayarakat Melayu. Keberadaan kesenian tradisional sesungguhnya merupakan wujud yang dapat dirasakan dan menunjukkan adanya kehidupan maupun pergerakan aktif di antara masyarakat Melayu. Hal ini menyebabkan kedudukan kesenian tradisional sebagai wujud penting yang nyata dari nilai budaya yang ada di lingkungan kebudayaan masyarakat Melayu (Abdullah, 2005). Akan tetapi minimnya pembahasan mengenai kesenian tradisional Melayu di wilayah Kota Batam justru menyebabkan kekosongan citra masyarakat dalam memandang kebudayaan Melayu di Kota Batam. Kesenian tradisional sebagai barisan terdepan pencitraan identitas Melayu justru tidak dapat menampilkan pencitraan identitas Melayu. Salah satu bentuk kesenian tradisional Melayu yang sesungguhnya eksis di antara masyarakat Melayu di Pulau Panjang Kota Batam adalah kesenian joget Dangkong.

Salah satu yang mencolok dalam tinjauan kesejarahan kesenian tradisional Joget Dangkong adalah perubahan yang mencolok dalam berbagai bentuk dan unsur yang terkandung dalam Joget Dangkong. Berbagai perubahan dapat dilihat dari adanya berbagai unsur material baru dalam penampilan Joget Dangkong adalah berbagai aksesoris tarian serta plot dari pertunjukan. Selain itu berbagai perubahan pada musik pengiring serta alat musiknya mengalami berbagai perubahan dalam bentuk tradisionalnya.

Berbagai perubahan di atas sangat tampak dalam kesenian tradisional Joget Dangkong di Pulau Panjang.Perubahan masyarakat pulau ke arah bentuk masyarakat perkotaan akibat lonjakan dan stimulan industri serta modernisasi menjadikan Kota Batam sebagai wilayah yang mengalami perubahan pesat. Hal ini pula yang menyebabkan terjadinya perubahan orientasi terhadap hiburan tradisional rakyat. Salah satunya adalah perubahan 
atas kesenian tradisional yang terjadi di dalam selera masyarakat dalam menikmati hiburan kesenian (Clifford, 1992).

Kondisi ini berpengaruh pula terhadap keberadaan kesenian tradisional Joget Dangkong. Turunnya minat masyarakat untuk menikmati hiburan tradisional disebabkan oleh berbagai faktor antara lain ketiadaan informasi, ketidaktahuan atas eksistensi kesenian tradisional joget dangkong serta berbagai kemunculan media hiburan baru seperti televisi ataupun sarana hiburan yang bersifat praktis dan individual.

Situasi tersebut tentu sangat berpengaruh terhadap kondisi seniman tradisional Joget Dangkong. Rendahnya minat masyarakat terhadap kesenian Joget Dangkong merubah berbagai pendapatan dan kehidupan keseharian seniman.Jika sebelumnya seniman tradisional Joget Dangkong menempati suatu lapisan dalam struktur sosial di antara masyarakat tradisional sebagai lapisan khusus kesenian. Akan tetapi dengan adanya perubahan sosial seniman turut larut dan adanya pergeseran bahkan marjinalisasi kedudukan seniman tradisional diantara masyarakat Pulau Panjang Kota Batam. Perubahan orientasi ikatan sosial dari ikatan yang bersifat komunal pada ikatan industrial menjadikan kelompok seniman tradisional terpisah dari struktur tradisional. Hal ini dikarenakan semangat dari kesenian tradisional lebih ditentukan oleh ikatan komunal dibandingkan dengan ikatan masyarakat perkotaan dengan mengandalkan adanya timbal balik materi dan bersifat instan. kajian penelitian ini bertujuan untuk; (1) Untuk mengetahui keberadaan joget dangkong dalam kesenian tradisional melayu, (2) mengetahui fungsi sosial budaya joged dangkong pada masyarakat Pulau Panjang

\section{Metode}

Penelitian ini tergolong pada jenis penelitian kualitatif. Penelitian kualitatif adalah penelitian yang dilakukan dengan latar belakang yang wajar dan alamiah serta holistik. Penelitian kualitatif berusaha melihat, mencermati, dan mengahayati masalah yang diteliti sebagai fenomena yang kompleks yang harus diteliti secara holistik atau menyeluruh (Maleong, 2000). Penelitian ini dilakukan di Pulau Panjang. Pemilihan lokasi di di Pulau Panjang karena Joget Dangkong berasal dari Pulau Panjang Kota Batam. Pemilihan informan dilakukan dengan sengaja sesuai dengan tujuan penelitian (purposive sampling). Kriteria pemilihan informan dilakukan berdasarkan tujuan penelitian dan memiliki wawasan pengetahuan yang luas serta pengalaman pribadi berkenaan dengan budaya Melayu, khususnya Joget Dangkong. Teknik pemilihan informan seperti ini memungkinkan untuk dilakukan karena 
peneliti sudah memahami para informaan yang diyakini mengerti dan mengetahui seluk-beluk budaya Melayu. Informan penelitian terdiri dari masyarakat Pulau Panjang, tokoh-tokoh adat, tokoh agama, serta orangorang yang berperan penting dalam budaya Melayu Joget Dangkong.

Teknik pengumpulan data dilakukan melalui observasi terhadap eksistensi kesenian tradisional Joget Dangkong di Pulau Panjang. Peneliti terlibat langsung serta mengamati tentang eksistensi kesenian tradisional Joget Dangkong di Pulau Panjang. Di samping melakukan pengamatan, peneliti juga melakukan wawancara mendalamsecara personal kepada informan dengan harapan agar dapat mengetahui gagasan dan pemahaman informan tentang kesenian tradisonal Budaya Melayu. Wawancara mendalam dilakukan untuk mengumpulkan data tentang keberadaan Joget Dangkong sebagai salah satu jenis kesenian tradisional Budaya Melayu dengan mengajukan pertanyaan berdasarkan pedoman wawancara yang telah dibuat sebelum ke lapangan.

Upaya lain yang dilakukan untuk mengumpulkan data penelitian adalah melalui FGD atau Focus Group Discussion (diskusi kelompok terarah). FGD adalah suatu proses pengumpulan informasi mengenai suatu masalah tertentu yang sangat spesifik, dalam penelitian ini terkait dengan masalah eksistensi kesenian tradisional Joget Dangkong dalam menghadapi tantangan globalisasi di Pulau Panjang. Peneliti melakukan diskusi dengan sekelompok orang yang dimintai pendapatnya tentang keberadaan joget dangkong.Pengujian keabsahan data penelitian dilakukan dengan teknik triangulasi data. Cara yang dilakukan adalah dengan memberikan pertanyaan-pertanyaan yang dianggap relatif sama terhadap informan yang berbeda untuk mengumpulkan data yang sama. Data dianggap absah apabila pertanyaan yang diajukan kepada informan yang berbeda diperoleh jawaban yang relatif sama. Data yang sudah valid kemudian dianalisis, sehingga terjawab semua pertanyaan penelitian yang disiapkan dalam pedoman wawancara.

Selanjutnya triangulasi data penelitian ini juga dilakukan dengan cara membandingkan data hasil pengamatan dengan data hasil wawancara, kemudian peneliti membaca ulang data secara sistemik (tersusun) dan memeriksa berulang kali. Data dianggap valid jika data yang diperoleh sudah relatif sama dari sumber yang berbeda. Apabila dengan kedua teknik pengumpulan data ini menghasilkan data yang berbeda-beda, maka peneliti menggali lagi informasi lebih dalam dan berdiskusi lebih lanjut dengan informan yang bersangkutan untuk memperoleh data yang benar adanya untuk dianalisis lebih lanjut.

Teknik analisa datayang digunakan dalam penelitian ini yaitu analisis etnografi dari Clifford Geertz dengan langkah-langkah sebagai berikut 
(Saefuddin, 2005). Pertama, hermeneutik data. Pada tahap hermeneutik data peneliti berusaha memperoleh sebanyak-banyaknya variasi data yang terkait dengan permasalahan penelitian. Peneliti memperoleh data mengenai Budaya Melayudimulai dari dasar pengetahuan orang-orang yang dikaji (the native). Selanjutnya dilakukan proses memerinci data, memeriksa data, membandingkan data, dan mengkategorikan data yang muncul dari hasil catatan lapangan mengenai budaya Melayu. Kedua, menginterpretasikan data. Menginterpretasikan data dilakukan dalam upaya menemukan makna setiap simbol. Geertz (1992) mengungkapkan makna dalam masyarakat harus berasal dari native point of view". Dengan demikian pada tahap ini dilakukan analisis hubungan antar kategori yang diperoleh dari hermeneutik data untuk kemudian disusun, diatur sesuai pokok permasalahan sehingga memudahkan menemukan makna pada setiap kategori.Interpretatif direpresentasikan. Ketiga, interpretatif direpresentasikan sesuai kenyataan yang dipaparkan yaitu apa yang dipahami oleh pelaku budaya sehingga berakibat terhadap pemaparan berbagai ungkapan mengenai Budaya Melayusecara panjang lebar yang disebut dengan thick description atau deskripsi tebal. Tujuannya agar dapat menggambarkan secara mendalam berbagai peristiwa berikut maknamakna yang terkandung di dalamnya (Syam, 2007).

\section{Hasil dan Pembahasan}

Fungsi Joget Dangkong sebagai saran hiburan. Oleh karena sifatnya yang bersifat profane, Joget Dangkong dapat berfungsi sebagai saran hiburan dalam pementasan tunggal atau pementasan pelengkap sebagai penutup atau acara hiburan setelah melakukan pentas utama. Fungsi Joget Dangkong sebagai hiburan pelengkap biasanya menutup acara dari pentas seni utama yang memiliki bobot lebih tinggi. Pada umumnya Joget Dangkong disisipkan atau dapat juga ditempatkan di bagian akhir setelah Drama Makyong. Materi Drama Makyong yang penuh nilai dianggap memiliki nilai-nilai filosofis kehidupan masyarakat Melayu. Hal ini menyebabkan pementasan Joget Dangkong sangat bermanfaat untuk meredakan ketegangan dan kejenuhan dari materi Drama Makyong yang panjang.

Situasi ini terjadi pada sebelum tahun 1990an ketika Drama Makyong masih menjadi salah satu favorit dari hiburan masyarakat perkampungan yang dianggap berbobot. Pada masa tersebut hiburan bagi masyarakat perkampungan khususnya di pulau-pulau di sekeliling pulau Batam masih sangat terbatas. Minimnya sarana hiburan seperti televisi dan radio sebagai sarana hiburan menyebabkan banyak hiburan seperti Drama Makyong dan Joget Dangkong sangat dinanti-nantikan oleh penduduk kampung. Hal ini 
Desma Yulia, Fitri Yanti

Eksistensi Kesenian Tradisional Joget Dangkong Di Pulau Panjang Kota Batam

terungkap dari penuturan Cik Normah yang menyatakan bahwa pementasan Drama Makyong dengan disertai Joget Dangkong di masa tersebut masih dapat dijadikan profesi untuk mata pencarian utama para penduduk perkampungan. Berikut penuturan Cik Normah.

“Pada masa lalu kami hanya berkeliling dari satu pulau ke pulau, penduduk akan senang menerima kami. Kami dapat menghabiskan waktu lebih dari satu minggu untuk pementasan Drama Makyong sekaligus Joget Dangkong" (Normah, 2014a).

Pernyataan tersebut kiranya harus dipahami bahwa pada masa lalu hiburan tradisional, terutama dengan menampilkan kesenian berbobot tinggi seperti Drama Makyong dengan Joget Dangkong merupakan bagian penting yang tidak dipisahkan dengan tradisi masyarakat pedesaan di pulau-pulau sekitar Batam. Penghargaan tinggi masyarakat pedesaan terhadap kesenian tradisional tampak bukan dari penghargaan atas nilai uang tetapi penghargaan atas pengganti jasa-jasa para seniman keliling dengan kemampuan yang dimiliki masyarakat pulau. Luasnya wilayah pementasan para seniman tradisional Pulau Panjang wilayah Kota Batam, Pulau Kasu di utara, Kampung Nongsa dan Batu Besar di Kota Batam pada batas sebelah timur, Kampung Air Lingka di sebelah selatan, dan Kepulauan Moro Karimun di sebelah barat menunjukkan besarnya minat masyarakat pedesaan terhadap kesenian di perkampungan.

Hal ini ditunjukkan cerita tentang pementasan tersebut sekitar tahun 1990an. Peristiwa di bawah ini adalah salah satu contoh tentang pementasan Drama Makyong dan Joget Dangkong ke pulau Seraya. Pementasan Drama Makyong dan Joget Dangkong biasanya memakan waktu perjalanan sekitar 3-4 jam dengan menggunakan tenaga dayung. Realitas ini menunjukkan bahwa pementasan Makyong dan Dangkong sangat disukai oleh masyarakat perkampungan pada periode sebelum tahun 1990an. Kondisi tersebut telah dimulai ketika perahu yang digunakan oleh para seniman Pulau Panjang untuk menyeberang laut kian mendekat ke wilayah Pulau Seraya. Para seniman yang masih berada di dalam perahu ketika mengetahui perahu akansegera berlabuh di Pulau Seraya, maka mereka akan menabuh gong tanda rombongan Dangkong telah tiba.

"Gemanya suara gong terdengar hingga ke kampung dan warga pulau Seraya sejak dari kejauhan menyambut dengan melambaikan tangan, berlari-lari di sepanjang pesisir pantai mengikuti jalur perahu hingga berteriak-teriak Dangkong. Setibanya di pelatar rumah penduduk di pulau Seraya, para warga mempersilahkan rombongan untuk beristirahat di salah 
satu rumah warga yang dikosongkan. Jika warga tidak memiliki uang dalam bentuk tunai, warga mengumpulkan beras dan berbagai barang kebutuhan pokok merekauntuk pengganti pementasan Drama Makyong mereka. Hal ini menandakan bahwa pementasan Drama Makyong kurang bersifat komersial." (Normah, 2014b)

Para seniman kemudian menerimanya dan kemudian mereka akan bersiap-siap untuk pementasan Drama Makyong. Pementasan tersebut dilaksanakan selepas maghrib. Narasumber menyebutkan bahwa pada masa tersebut masih belum ada Masjid ataupun Surau yang menandakan waktu maghrib melalui suara Adzan sehingga penentuan waktu pementasan akan dilakukan selepas matahari tenggelam. Penduduk pulau Seraya telah menanti di pekarangan rumah agar tidak tertinggal satu-satunya hiburan pada masa tersebut.Kaum seniman sendiri menyiapkan suatu tanah lapang berbentuk persegi atau persegi panjang yang cukup luas dengan panjang sisi sekitar 7-10 $m$ sebagai panggung pementasan. Panggung ini tentu tidak seperti pada gambaran panggung di masa kini. Pada keempat ujung sisinya ditancapkan obor dan sesajian khusus. Kemudian pemimpin kelompok seniman mengambil posisi di tengah panggung dan membacakan doa-doa untuk meminta ijin dari roh penunggu tanah.

Setelah itu pementasan dimulai dengan permainan musik, nyanyian, dan masuk kepada dialog dalam Drama Tradisional Makyong. Dialog pada Drama Makyong memiliki banyak babak. Satu babak kurang lebih menghabiskan waktu pementasan sekitar 2-3 jam.Setelah satu babak selesai biasanya diadakan jeda waktu. Jeda waktu tersebut dimanfaatkan oleh para pementas tari yang hampir seluruhnya adalah kaum pria terkecuali pemeran rajanya yang harus perempuan.Pada saat jeda tersebut kaum seniman wanita yang masih muda biasanya mengisi dengan melakukan Joget Dangkong meskipun minimal hanya tiga lagu wajib sebagai lagu pembuka.Jika memang tidak diadakan Joget Dangkong, maka pementasan babak berikutnya dari Drama Makyong terus berjalan.Pementasan di tengah-tengah jeda atau masa istirahat pada peralihan babak sangat tergantung dari situasi yang bersifat temporer.

Jika Joget Dangkong memang belum terlaksana hingga pementasan Drama Makyong berakhir, Joget Dangkong dilaksanakan pada akhir acara. Pementasan Joget Dangkong juga membutuhkan suatu situasi khusus. Tetapi pada umumnya Joget Dangkong yang dilakukan setelah pementasan Drama Makyong menggunakan panggung yang sama dengan dipentaskannya Drama Makyong.Pada saat pementasan Joget Dangkong terjadi perubahan suasana. 
Desma Yulia, Fitri Yanti

Eksistensi Kesenian Tradisional Joget Dangkong Di Pulau Panjang Kota Batam

Jika sebelumnya suasana sangat dipengaruhi oleh kekhusukan dan larutnya penonton dalam emosi yang dipengaruhi oleh alur cerita Drama Makyong, pada saat Joget Dangkong emosi penonton kemudian meledak menjadi suatu partisipasi aktif dan ketidaksabaran penonton untuk terlibat dalam Joget Dangkong.

Penonton harus tetap menanti para wanita yang menarikan Joget Dangkong menyelesaikan tiga buah lagu yang dinyanyikan oleh sang penyanyi wanita. Hal ini juga berguna bagi para penonton untuk melihat dan membandingkan dari masing-masing penari baik dari segi kecantikan, keelokan, hingga keluwesan menari yang akan menjadi pertimbangan penting bagi para penonton untuk memilih pasangan menarinya kelak.Fungsi tarian pasangan antara pria dan wantia sesungguhnya menunjukkan adanya hubungan kuat antara tari Joget Dangkong dengan fungsinya sebagai media sosial. Tarian Joget Dangkong berpasangan seringkali tidak harus melibatkan antara penari Joget Dangkong dengan para penontonya, tetapi juga dapat melibatkan para penonton pria dengan penonoton wanita. Hal ini menjadi ajang untuk berpasang-pasangan antara suami dan istri atau antara kekasih untuk mencari pasangan hidup.

Perbedaan utamanya adalah pasangan penari antara penton dengan penonton tidak membutuhkan biaya, sedangkan pemilihan pasangan menari antara penonton dengan penari diharuskan membayar dengan nilai ekonomis dan komersial tertentu.Tentu situasi tersebut membuktikan bahwa Joget Dangkong bersifat komersial. Jika sebelumnya Drama Makyong memberi ruang keikhlasan kepada penduduk untuk memberi penghargaan terhadap berbagai nilai dan norma sosial, maka Joget Dangkong justru mengabaikan fungsi religiusisitasnya. Pemberian komersial biasanya dilakukan di atas panggung atau yang lebih dikenal dengan sawer antara penonton dengan penari Joget Dangkong.Berdasarkan hasil wawancara dengan Bapak Darwin, tokoh masyarakat di Pulau Panjang yang juga sebagai penikmat Joget Dangkong menyatakan sebagai berikut:

“Joget Dangkong merupakan hiburan bagi masyarakat tradisional Melayu. Dalam Joget Dangkong menampilkan kebersamaan dan kerjasama di antara sesama. Hubungan antara pria dan wanita yang menari masih sangat sopan. Hal ini justru layak untuk dipertahankan sebagai wujud budaya ketimuran dan sopan santun. Joget Dangkong harus didukung pemerintah daerah sebagai kesenian tradisional karena mengandung nilai-nilai ketimuran seperti sopan santun dari pakaian dan gerakan tarinya" (Darwin, 2014) 
Hal yang agak berbeda terjadi ketika Joget Dangkong diperuntukkan untuk pentas tunggal.Seringkali Joget Dangkong yang sangat popular pada tahun-tahun 1980an benar-benar menunjukkan komersialitasnya. Para penari Joget Dangkong yang berusia belasan tahun memang dipersiapkan untuk tidak bersekolah karena pada masa tersebut perempuan berusia belasan tahun menjadi idola di antara penonton.Tidak sekolahnya para penari wanita dikarenakan waktunya berselisih dengan kegiatan berkeliling ke pulau-pulau.

Fungsi kesenian Joget Dangkong khususnya di antara masyarakat Pulau Panjang dan masyarakat Batam memiliki fungsi sebagaimana kesenian tradisional lainnya. Hal ini sesuai dengan konsep kesenian tradisional yang memiliki beberapa fungsi yaitu pemujaan, tuntunan dan hiburan. Maksud dari seni sebagai pemujaan atau ritual berarti bahwa seni berlangsung pada masa peradaban manusia masih terbelakang. Kecenderungan seni ritual pada masa lampau lebih menekankan pada misi daripada fisik atau bentuk. Tidak mengherankan kalau bentuk seni ritual untuk pemujaan masih sangat sederhana, baik dari aspek musik ringan, busana (kostum) serta rias, gerak maupun penggunaan dekorasi sebagai latar atau settingpertunjukan. pada saat ini kita masih dapat menemui jejak-jejak seni yang berperan sebagai ritual atau pemujaan, misalnya Tari Barong pada upacara di Bali.

Fungsi kesenian sebagai tuntutan lebih menyentuh pada misi yang secara verbal diungkapkan.Dalam hal ini pelaku seni lebih dituntut menyampaikan pesan moral. Misalnya seorang dalang harus mampu memerankan tokoh yang ada dalam kotak wayangnya. Dalang harus mampu membawakan diri dan memilah mana tokoh simbol angkara murka dan mana tokoh simbol kebaikan. Dimensi inilah yang mewarnai tuntunan dibalik sebuah tontonan. Fungsi terakhir seni adalah untuk tontonan atau hiburan. Dalam hal ini seni yang menghibur adalah seni yang mampu memberi kesenangan pada seseorang atau kelompok orang yang ada disekitar pertunjukan Joget Dangkong.

Joget Dangkong merupakan kesenian tradisional yang hidup di dua masa sekaligus yaitu tradisional dan modern. Meskipun Joget Dangkong termasuk pada kesenian tradisional, Joget Dangkong juga hidup di masa modern semacam ini. Melihat hal tersebut ada baiknya ditinjau dari apresiasi kesenian Joget Dangkong.Keberadaan Joget Dangkong memiliki tempat sebagai jati diri kesenian tradisional diantara penduduk yang berkebudayaan Melayu. Hal ini tampak dari adanya apresiasi seni masyarakat Melayu terhadap Joget Dangkong. Pengertian apresiasi tidak terbatas pada kemampuan mengungkap misi, baik yang menyampaikan (berupa karya) maupun yang menerima misi (peminat seni).Pada prinsipnya, apresiasi seni 
Desma Yulia, Fitri Yanti

Eksistensi Kesenian Tradisional Joget Dangkong Di Pulau Panjang Kota Batam

merupakan aktivitas mental yang mencakup penghargaan yang bersifat subjektif.

Melalui pengamatanterhadap apresiasikesenian tradisional Joget Dangkong dapat dikatakan sebagai ekspresi jiwa manusia melalui gerakangerakan ritmis yang indah. Batasan tersebut dapat menunjukkan bahwa media dasar seni tari adalah gerak, semua gerak badanJoget Dangkong yang tidak baku juga dapat dikatakan sebagai seni. Hal tersebut menunjukkan bahwa makna indah pada Joget Dangkong berarti jika seorang penari dalam membawakan tarian sesuai dengan perwatakan dan karakter yang dituntut dari tarian yang dimainkan.

Berdasarkan hal tersebut kedudukan Joget Dangkong dapat dikatakan sebagai seni hiburan dalam masyarakat tradisional. Hal ini tampak dari keberadaan Joget Dangkong yang menampilkan peranannya sebagai hiburan menyebabkan Joget Dangkong begitu diminati pada masa lampau karena kesenian tradisional Joget Dangkong bukanlah kesenian yang terlalu rumit namun berisikan materi yang ringan.Joget Dangkong sebagai kesenian tari tradisional sebagai media pergaulan berarti bahwa penggarapan atau pementasan Joget Dangkong melibatkan beberapa orang.Oleh karena itu, kegiatan kesenian tradisional Joget Dangkong dapat berfungsi sebagai sarana pergaulan.Hal ituterlihat dari pementasan Joget Dangkong yang melibatkan penari dan penonton pertunjukkan. Biasanya Joget Dangkong yang melibatkan para penonton akan menari secara berpasang-pasangan antara pria dan wanita namun masih terbatas pada etika dan norma-norma sosial yang layak dalam masyarakat umum Melayu. Walaupun demikian Joget Dangkong dapat menjadi ajang pergaulan bagi seluruh penonton untuk bersenang-senang atau terlibat dalam kegembiraan tarian tersebut.

Kedudukan Joget Dangkong lainnya adalah sebagai pertunjukan yang sengaja digarap untuk dipertontonkan. Hal ini dapat ditunjukkan bahwa Joget Dangkong memiliki persiapan yang baik, mulai dari latihan hingga pementasan, dipersiapkan dengan penuh perhitungan. Hal ini sesuai dengan pernyataan sebagai berikut:

"Meski Joget Dangkong berupa kesenian hiburan dan seringkali penonton terlibat dengan berbagai jenis tarian, tari yang dipentaskan sesungguhnya lebih menitikberatkan pada segi artistiknya, penggarapan koreografi yang mantap, mengandung ide-ide, interpretasi, konsepsional serta memiliki tema dan tujuan. Pada umumnya, tari-tari tradisional digarap secara baik dan memperhatikan kaidah-kaidah seni pertunjukan sehingga tari tradisional merupakan seni yang bernilai artistik tinggi.Hal ini dapat dilihat dari adanya persiapan musik pengiring untuk 
berlatih jenis-jenis lagu yang telah dipilih, penyanyi yang menyanyikan vokal dengan lirik lagu tertentu, dan keberadaan para penari Joget Dangkong yang menunjukkan adanya keluwesan dan tarian tertentu." (Zamri, 2014).

Meskipun Joget Dangkong pernah melalui masa kejayaannya pada dekade sebelum tahun 1970an,kemerosotan Joget Dangkong berlangsung secara perlahan sejak dekade 1980an dan terus menurun pada dekade 2000an. Hal ini disebabkan adanya pergeseran dan perubahan diantara masyarakat pendukungnya.

Menurut penuturan Bapak Dorani:

"Nostalgia atas Joget Dangkong tampak dalam gambaran bahwa di masa lalu banyak warga kampung adalah kaum penggila joget.Banyak sekali anak-anak muda jaman dulu berhabis duit demi bisa untuk turun ngebeng atau menari. Sejak masa lalu telah umum dikenal bahwa jika sudah terdengar gong dari kelompok joget, semua pekerjaan ditinggalkan demi berjoget. Oleh karena itu banyak istri yang marah karena tidak hanya buang uang tapi adapula yang bermain serong dengan penari atau anak panggung," (Dorani, 2014).

Popularitas Joget Dangkong kian menurun sejak tahun 2000an. Hal tersebut tentu berhubungan dengan perubahan-perubahan yang terjadi pada Joget Dangkong. Perubahan yang terjadi adalah; pertama, perubahan ekonomi. Salah satu persoalan utama adalah konsekuensi ekonomi yang harus dihadapi jika masih menggeluti Joget Dangkong sebagai mata pencaharian utama. Hal ini tampak dari bagaimana permasalahan ekonomi terutama dalam pemenuhan kebutuhan hidup menjadi persoalan serius. Beberapa narasumber menyebutkan bahwa Joget dahulu tidak sama dengan sekarang terkait dengan bayaran. Pada masa lampau grup joget membuka panggung sendiri.Kadang para seniman menetap hampir satu bulan di suatu kampung kemudian barulah ke desa lainnya. Pada masa lampau Joget Dangkong bahkan dapat diadakan dalam ruang terbatas dengan tiket penonton. Penonton yang hendak menari harus membeli tiket dari penyelenggara sehingga yang tidak memiliki tiket tidak boleh ngebeing. Hal ini sering menyebabkan terjadinya perkelahian antara sesama penonton yang tidak mendapat tiket.

Hal ini tentu sangat berbeda dengan keberadaan pementasan Joget Dangkong pada tahun 2014. Keterbatasan pementasan Joget Dangkong tidak mampu menawarkan keberhasilan ekonomi kepada para seniman Joget 
Dangkong.Banyak di antara para seniman kemudian memilih mata pencahairan di luar Joget Dangkong. Ada yang menjadi nelayan, pekerja di Kota Batam dan bahkan keluarga seniman Lime Saudare khususnya Cik Normah dan Bapak Dorani memilih untuk berwiraswasta dengan cara berdagang. Kedua, munculnya hiburan baru. Ketidak-mampuan Joget Dangkong untuk tetap eksis seperti pada masa lampau dikarenakan adanya kemunculan media informasi dan hiburan baru. Televisi, DVD dan internet lebih digemari dan jauh lebih populer dikalangan masyarakat. Kesenian dan hiburan yang ada di masa lampau merupakan kegiatan sosial melalui aktivitas interaksional dan berperan sebagai media sosial seperti Joget Dangkong, namun sekarang dapat dinikmati secara individual di dalam rumah tanpa harus mengeluarkan biaya tinggi.

Berbagai perubahan tersebut tentu menyebabkan adanya perubahan sosial di dalam lingkungan masyarakat pendukung kesenian Joget Dangkong.Berbagai perubahan mendorong masyarakat memiliki orientasi kesenian yang berbeda baik dari fungsi maupun tujuannya.Salah satunya adalah peralihan tradisi Joget Dangkong kepada Joget yang diiringi oleh organ tunggal. Meski tidak dapat diabaikan bahwa Joget Dangkong sangat mempengaruhi bentuk kesenian tradisional tersebut.Joget organ tunggal mampu memberi tawaran baru atas sensualitas dari pementasannya baik pada gerak tari maupun lirik lagu yang memenuhi kebutuhan atas budaya populer yang sekarang tengah didukung oleh sebagian besar masyarakat pendukung kesenian Joget Dangkong yaitu masyarakat Melayu.

\begin{abstract}
"Joget saat kini menjadi idola baru.Penampilan joget yang sesuai dan berpakaian seronok lebih disukai terutama oleh kaum pria.Gerakan Joget Dangkong cenderung sopan dan kurang menarik. Gerakan joget bebas. Lagunya pun bukan lagu Melayu karena lagu Melayu kurang menarik untuk kaum muda.Lagunya pun adalah lagu-lagu disko atau dangdut karena lebih menarik dibandingkan lagu Melayu.Musiknya biasanya hanya organ tunggal bahkan sekarang hanya menggunakan flashdisk atau DVD." (Abdullah, 2014).
\end{abstract}

Saat ini kejayaan Joget Dangkong merupakan nostalgia masa lalu. Hanya orang-orang tua yang memiliki harapan untuk merasakan kembali berjoget Dangkong bukan untuk hiburan semata tetapi juga mengingat masa muda mereka.

\title{
Simpulan
}

Berdasarkan dari pembahasan bab sebelumnya maka dapat diambil beberapa kesimpulan yaitu; unsur-unsur kesenian Joget Dangkong adalah 
musik, lagu pengiring dan ornament-ornamen kesenian. Musik pada Joget Dangkong berkenaan dengan berbagai musik yang menjadi lagu wajib pada Joget Dangkong adalah Tabik, Serampang Laut dan Mata Laut Inang. Di masa lalu para pemusik memainkan gendang dan di masa kini memainkan kompang, gong, akordeon, dan di masa kini dengan tambahan alat music keyboard atau organ. Sedangkan ornamen seni terdiri dari beberapa unsur yaitu panggung yang berupa petak lahan dan kini menjadi panggung secara teratur, alat penerangan berupa obor dan ornamen berupa kostum dan tata rias. Khusus mengenai kostum akan lebih menekankan kepada bentuk atau jenis pakaian, beberapa alat kelengkapan dan perhiasan.Fungsi sosial dan kedudukan Joget Dangkong antara lain berkedudukan sebagai kesenian profane dan berfungsi sebagai hiburan dan media pergaulan sosial.Berbagai perubahan memang terjadi pada kesenian Joget Dangkong. Perubahan yang terjadi justru merugikan ataupun kurang menguntungkan bagi perkembangan kesenian Joget Dangkong di masa kini dibandingkan di masa lalu. Secara garis besar berbagai perubahan tersebut diakibatkan oleh perkembangan media informatika terbaru dengan kemunculan televisi, handphone dan berbagai alat hiburan lainnya.Perubahan sosial akibat adanya pergeseran orientasi ekonomi dan perilaku penduduk, dan Kemunculan kesenian joget dengan diiringi organ tunggal yang merupakan perkembangan dari Joget Dangkong.

\section{Daftar Rujukan}

Abdullah. (2014). Wawancara Mengenai Joget Dangkong, tanggal 10 Juni 2014. Batam.

Abdullah, I. (2005). Konstruksi dan Reproduksi Kebudayaan. Yogyakarta: Pustaka Pelajar.

Clifford, G. (1992). Tafsir Kebudayaan. Yogjakarta: Kanisius.

Darwin. (2014). Wawancara tanggal 2 Juni, dengan tokoh masyarakat di Pulau Panjang sebagai penikmat Joget Dangkong. Batam.

Dorani. (2014). wawancara mengenai Nostalgia atas Joget Dangkong,tanggal 10 Juni, 2014. Batam.

Geertz, C. (1992). Kebudayaan \& agama. Yogjakarta: Penerbit Kanisius.

Maleong, L. (2000). Metode Penelitian Kuantitatif Dan Kualitatif. Bandung: Remaja Rosda.

Normah, C. (2014a). Wawancara mengenai pementasan Drama Makyong tanggal 8 Juni, 2014. Batam.

Normah, C. (2014b). Wawancara tanggal 9 Juni, mengenai pementasan Drama Makyong dan Joget Dangkong ke pulau Seraya sekitar tahun 1990an. Batam. 
Desma Yulia, Fitri Yanti

Eksistensi Kesenian Tradisional Joget Dangkong Di Pulau Panjang Kota Batam

Saefuddin, A. F. (2005). Antropologi Kontemporer. Jakarta: Kencana.

Syam, N. (2007). Mazhab-mazhab Antropologi. Yogyakarta: LkiS.

Zamri. (2014). Wawancara tanggal 8Juni 2014, mengenai Kedudukan Joget Dangkong. Batam. 